\title{
Biomass Accumulation and Industrial Yield of Irrigated Sugarcane Submitted to Sources and Doses of Nitrogen Grown in Cerrado Oxisol
}

\author{
N. F. da Silva ${ }^{1}$, F. N. Cunha ${ }^{1}$, M. B. Teixeira ${ }^{1}$, F. A. L. Soares ${ }^{1}$, E. C. da Silva ${ }^{1}$, R. D. Coelho ${ }^{2}$, \\ F. R. Cabral Filho ${ }^{1}$, L. C. de M. Silva ${ }^{1} \&$ W. S. da S. Cavalcante ${ }^{3}$ \\ ${ }^{1}$ IF Goiano, Campus Rio Verde, Rio Verde, Brazil \\ ${ }^{2}$ ESALQ/USP, Piracicaba, Brazil \\ ${ }^{3}$ IESRIVER, Instituto de Ensino Superior de Rio Verde/Faculdade Objetivo, Brazil \\ Correspondence: N. F. da Silva, Hydraulic and Irrigation Laboratory, IF Goiano, Campus Rio Verde, Rio Verde, \\ Brazil. E-mail: nelmiciofurtado@gmail.com
}

Received: March 4, 2019

doi:10.5539/jas.v11n9p167
Accepted: April 26, $2019 \quad$ Online Published: June 30, 2019

URL: https://doi.org/10.5539/jas.v11n9p167

\begin{abstract}
The sugar and alcohol sector have invested heavily in technologies to increase the productivity of sugarcane and consequently the gross income of sugar and alcohol; among these practices irrigation and fertilization stands out. Based on the hypothesis that the source and the availability of nitrogen influence the growth, development and yield of irrigated sugarcane in the cerrado region, this study aimed to evaluate the accumulation of biomass and yield to define the best source and dose of nitrogen fertilization in irrigated sugarcane, in the cane-plant cycle, in a very clayey dystrophic Red Latosol, cerrado phase. The experiment was carried out at the Raízen Plant, located in the municipality of Jataí-GO. Brazil. The variety IACSP95-5000 was used in a randomized block experimental design, analyzed in a split-split-plot scheme, with four replicates. The factors evaluated were in the plots of four $\mathrm{N}$ rate $\left(0,60,120\right.$ and $\left.180 \mathrm{~kg} \mathrm{ha}^{-1}\right)$; In the split-plot two $\mathrm{N}$ sources (urea and ammonium nitrate) and as split-split-plot were represented by four evaluation periods (210, 250, 290 and 330 days after the planting-DAP). The irrigation was by sprinkling, performed by a central pivot. The highest gross sugar yield and gross alcohol yield in the average source of $131.72 \mathrm{~kg} \mathrm{~N} \mathrm{ha}^{-1}$ had an average increase of $32.19 \%$, compared to without $\mathrm{N}$ application $0 \mathrm{~kg} \mathrm{~N}$ $\mathrm{ha}^{-1}$.
\end{abstract}

Keywords: Saccharum spp., IACSP95-5000, nitrogen fertilization, cerrado, Brazil

\section{Introduction}

Sugarcane is a historically important and strategic agricultural crop for Brazil, presents an increasingly diversified and flexible production chain and directly contributes to making the Brazilian energy matrix cleaner and more renewable. However, in order to produce ethanol that meets the needs of our country, and also to export this fuel, there is a need for large areas planted with the crop. Due to this, sugarcane producers and agro-industries in the sugar-alcohol sector have invested heavily in technologies to increase crop productivity and improve the industrial quality of the raw material (Dantas Neto et al., 2006), irrigation and fertilization can be mentioned as these investment in management (Lelis Neto, 2012). The increase in sugarcane productivity with the use of irrigation is well known (Wiedenfeld \& Enciso, 2008; Gava et al., 2011). Nevertheless, the improvement of the management techniques becomes necessary to reach the maximum efficiency in the use of the fertilization, aiming at maximum productivity, especially when dealing with nitrogen fertilization.

The productive characteristics and growth is strongly influenced by the potential of adaptation of the varieties to the climate, especially to the temperature and rainfall regime, as well as to the cultural practices used (Lima \& Alves, 2008). Among the environmental factors that most influence the conversion of energy to sugar by the sugarcane crop, we can mention: solar energy (intensity, duration and quality); the concentration of $\mathrm{CO}_{2}$; the temperature; and the availability of water and nutrients, especially nitrogen $(\mathrm{N})$, which has great importance for being a component of proteins, among other biomolecules (Gava et al., 2010). For Donaldson et al. (2008) and Van Heerden et al. (2010) when adequate water availability, solar radiation and high temperatures occurs, the nutrient supply becomes the main limiting factor and may affect the increase of the biomass accumulation. 
In the soil-plant-atmosphere system, $\mathrm{N}$ is one of the most limiting elements of plant growth (Moreira \& Siqueira, 2006). Among the mineral elements, $\mathrm{N}$ is essential for plant life because it is part of the composition of most organic compounds, such as amino acids, proteins, nucleic acids, hormones and chlorophyll (Malavolta, 2006). Thus, $\mathrm{N}$ is considered the most important mineral macronutrient in the chemical composition of plants (Raij, 1991). In addition, it participates in the main biochemical reactions of plant metabolism and has important participation in the biogeochemical cycles, which are controlled by physical, chemical, and biological factors and affected by difficult and predictive climatic conditions. The reduction of nitrate to ammonium and the incorporation of these in plants account for a quarter of the energy expenditure of plants (Epstein \& Bloom, 2005).

$\mathrm{N}$ fertilizer in sugarcane grown is performed in different doses and forms of application depending on the age of the crop, planting and cutting season, production environment and irrigation use. As in other crops the harvest expectation reflects the amount of fertilizer to be applied, the dose and the form (Schultz et al., 2015). According to Vitti et al. (2008), the advances in research with genetic improvement and the creation of more productive materials are probably leading to an underestimation of the potential economic response to $\mathrm{N}$ in sugarcane.

In the different agricultural environments, the productivity of Brazilian sugarcane plantations has been limited, mainly, by water restrictions and the availability of nutrients in soils. In this context, it becomes necessary to re-evaluate the nutritional requirements of sugarcane planted today, as well as nutrient doses in cane-plant fertilization. Based on the hypothesis that the $\mathrm{N}$ source and the availability of nitrogen influence the growth, development and productivity of the irrigated sugarcane in the Brazilian Cerrado region, this study aimed to evaluate the accumulation of biomass and yield to define the best source and dose of nitrogen fertilization in irrigated sugarcane, in the cane-plant cycle, grown in a very clayey dystrophic Red Latosol, Cerrado.

\section{Material and Methods}

The experiment was carried out under field conditions, during the 2014/2015 crop season, in an area at Rio Paraíso II Farm (Raízen Plant, in the municipality of Jataí, GO). The geographical coordinates of the site are $17^{\circ} 44^{\prime} 2.62^{\prime \prime} \mathrm{S}$ and $51^{\circ} 39^{\prime} 6.06^{\prime \prime} \mathrm{W}$, with an average altitude of 907 meters. According to the classification of Köppen and Geiger (1928), the climate of the place is type Aw, tropical, with rainfall from October to April, and dries from May to September. The maximum temperature ranges from 35 to $37^{\circ} \mathrm{C}$, and the minimum of 12 to $15^{\circ} \mathrm{C}$ (in the winter there are occurrences of up to $5{ }^{\circ} \mathrm{C}$ ). The annual precipitation reaches approximately $1,800 \mathrm{~mm}$, but poorly distributed throughout the year, according to the climatic data shown in Figure 1.

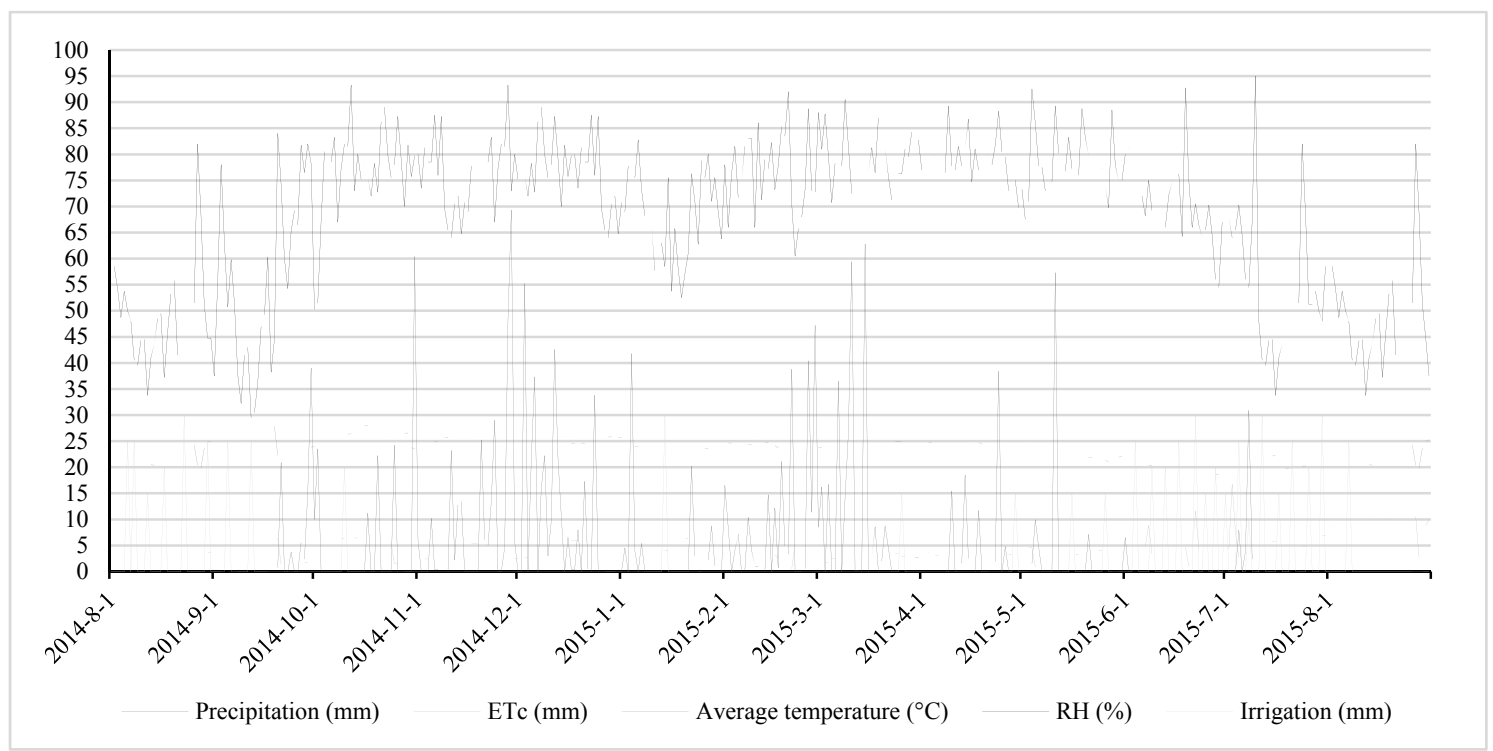

Figure 1. Daily water balance in the period resulting from the experiment, Jataí-GO, Brazil, crop season 2014/15 Source: INMET Normal Station-Jataí-GO.

The soil of the experimental area is classified as Dystropherric Typic Rhodic Hapludox soil (Soil Taxonomy, 2010) and dystroferric Red Latosol, very loamy, Cerrado (savanah) phase (Santos et al., 2013). The experimental 
area has a history of renovation of the sugarcane plantation of seven years of cultivation. The chemical, physical-water, granulometry and textural classification of the samples collected previous to the installation of the experiment are described in Table 1.

Table 1. Chemical, physical-water, granulometry and soil textural classification of the experimental area, 0-0.10, 0.10-0.20 and 0.20-0.40 m depth, Jataí-GO, Brazil, crop season 2014/15

\begin{tabular}{|c|c|c|c|c|c|c|c|c|}
\hline Layers & $\mathrm{pH}$ & O.M. & $P_{\text {Resin }}$ & $\mathrm{S}$ & $\mathrm{K}$ & $\mathrm{Ca}$ & $\mathrm{Mg}$ & $\mathrm{Al}$ \\
\hline $\mathrm{m}$ & $\mathrm{CaCl}_{2}$ & $\mathrm{~g} \mathrm{dm}^{-3}$ & \multicolumn{2}{|c|}{------- $\mathrm{mg} \mathrm{dm} \mathrm{dm}^{-3}$} & \multicolumn{4}{|c|}{---------------- $\mathrm{mmol}_{\mathrm{c}} \mathrm{dm}^{-3}$-------------- } \\
\hline $0-0.10$ & 5.9 & 72 & 45 & 13 & 9.9 & 53 & 22 & $<1$ \\
\hline $0.10-0.20$ & 5.6 & 46 & 13 & 26 & 12.1 & 31 & 12 & $<1$ \\
\hline $0.20-0.40$ & 5.2 & 41 & 8 & 91 & 8.9 & 15 & 6 & $<1$ \\
\hline Layers & $\mathrm{H}+\mathrm{Al}$ & CEC & $\mathrm{V}$ & $\mathrm{B}$ & $\mathrm{Cu}$ & $\mathrm{Fe}$ & $\mathrm{Mn}$ & $\mathrm{Zn}$ \\
\hline $\mathrm{m}$ & \multicolumn{2}{|c|}{------ $\mathrm{mmol}_{\mathrm{c}} \mathrm{dm}^{-3}$------ } & $\%$ & \multicolumn{5}{|c|}{--------------------------- mg dm³ } \\
\hline $0-0.10$ & 22 & 106.9 & 79 & 0.28 & 1.2 & 39 & 3.4 & 2.1 \\
\hline $0.10-0.20$ & 28 & 83.1 & 66 & 0.17 & 1.6 & 36 & 1.6 & 1.0 \\
\hline $0.20-0.40$ & 21 & 60.9 & 49 & 0.12 & 1.4 & 25 & 0.7 & 0.3 \\
\hline \multirow{2}{*}{ Layers } & \multicolumn{3}{|c|}{ Granulometry } & \multirow{2}{*}{\multicolumn{2}{|c|}{ Textural classification }} & \multirow{2}{*}{$\theta_{\mathrm{CC}}$} & \multirow{2}{*}{\multicolumn{2}{|c|}{$\theta_{\mathrm{PMP}}$}} \\
\hline & Sand & Silt & Clay & & & & & \\
\hline $\mathrm{m}$ & \multicolumn{5}{|c|}{ 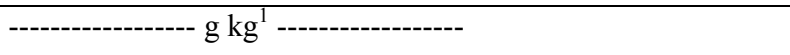 } & \multicolumn{3}{|c|}{---------- $\mathrm{cm}^{3} \mathrm{~cm}^{-3}$} \\
\hline $0-0.10$ & 96 & 82 & 822 & \multicolumn{2}{|c|}{ Clayey } & 463 & \multirow{2}{*}{\multicolumn{2}{|c|}{22.6}} \\
\hline $0.10-0.20$ & 97 & 82 & 822 & \multicolumn{2}{|c|}{ Clayey } & & & \\
\hline $0.20-0.40$ & 85 & 71 & 845 & Claye & & 45.8 & \multicolumn{2}{|c|}{22.6} \\
\hline
\end{tabular}

Note. Manual of chemical analysis for fertility evaluation of tropical soils (Raij et al., 2001). O.M.-Organic matter; CEC-Cation exchange capacity; V-Bases saturation; $\theta_{\mathrm{CC}}-$ Water content in field capacity; $\theta_{\mathrm{PMP}}$-Water content at the permanent wilting point.

The experimental design was a randomized block, analyzed in a $4 \times 2$ factorial scheme, with three replicates. The treatments were four rates of fertilizer labeled with ${ }^{15} \mathrm{~N}$ isotope $\left(30,60,120\right.$ and $\left.180 \mathrm{~kg} \mathrm{~N} \mathrm{ha}{ }^{-1}\right)$; two $\mathrm{N}$ sources of fertilizer labeled with ${ }^{15} \mathrm{~N}$ isotope (urea and ammonium nitrate).

$\mathrm{N}$ fertilization was performed according to the treatments, at 60 days after planting, applied to haul, on the line side $(0.20 \mathrm{~m})$, contrary to the slope of the land. All treatments were fertilized at planting with phosphorus $\left(100 \mathrm{~kg} \mathrm{ha}^{-1}\right.$ of $\left.\mathrm{P}_{2} \mathrm{O}_{5}\right)$ as triple superphosphate, potassium $\left(80 \mathrm{~kg} \mathrm{ha}^{-1}\right.$ of $\left.\mathrm{K}_{2} \mathrm{O}\right)$ as potassium chloride, and micronutrients, according to the results from soil analysis and recommendation of Sousa and Lobato (2004).

Soil preparation was performed by the conventional system, by means of plowing and harvesting, followed by opening of the machining planting grooves, according to the experience of the plant the number of buds per meter, according to the recommendations for the respective variety. The variety used was the IACSP95-5000.

The herbicides, insecticides, fungicides and other products for control of invasive plants, pests and diseases were used whenever necessary.

The irrigation was carried out by a central pivot ZIMMATIC, monitoring the irrigation following the farmer recommendation. During the crop cycle, meteorological data of maximum and minimum temperature $\left({ }^{\circ} \mathrm{C}\right)$, maximum and minimum relative humidity $(\%)$, wind speed $\left(\mathrm{m} \mathrm{s}^{-1}\right)$, solar radiation $\left(\mathrm{kJ} \mathrm{m}^{2}\right)$ and rainfall precipitation were collected daily $(\mathrm{mm})$, through a meteorological station. The water balance and the soil water balance were generated with the aid of irrigation management software (IRRIGER ${ }^{\circledR}$ ). In the software, climate monitoring is used to estimate the daily water consumption of sugarcane, for the irrigation blade to be applied, at the appropriate moment to irrigate. The software uses the Penman-Monteith method (FAO Standard, 1991), adapted by Allen et al. (1989) for the estimation of evapotranspiration on a daily scale, with micrometeorological data of solar radiation, air temperature, wind speed and relative humidity.

The monitoring the irrigation following the farmer recommendation. During the crop cycle, meteorological data of maximum and minimum temperature $\left({ }^{\circ} \mathrm{C}\right)$, maximum and minimum relative humidity $(\%)$, wind speed $\left(\mathrm{m} \mathrm{s}^{-1}\right)$, solar radiation $\left(\mathrm{kJ} \mathrm{m}^{2}\right)$ and rainfall precipitation were collected daily $(\mathrm{mm})$, through a meteorological station. The water balance and the soil water balance were generated with the aid of irrigation management software $\left(\right.$ IRRIGER $^{\circledR}$ ). In the software, climate monitoring is used to estimate the daily water consumption of sugarcane, for the irrigation blade to be applied, at the appropriate moment to irrigate. The software uses the Penman-Monteith 
method (FAO Standard, 1991), adapted by Allen et al. (1989) for the estimation of evapotranspiration on a daily scale, with micrometeorological data of solar radiation, air temperature, wind speed and relative humidity.

Two tillers were collected in the central lines of the subplots to evaluate the variables plant dry matter of green leaves (DMGL), dry matter of dead leaves (DMDL), dry matter of stem (DMS) and dry matter of pointer (DMPT). Two plants were collected and then dried in a forced air circulation oven at $65^{\circ} \mathrm{C}$ until constant mass, and the dry matter mass of each part of the plant was determined. The sum of the values corresponding to the biomass of each structural component of the plants (DMGL + DMDL + DMS + DMPT) allowed the determination of the total dry matter of shoot (TDMS), according to Marafon (2012):

$$
\text { TDMS }=\text { DMGL }+ \text { DMDL }+ \text { DMS }+ \text { DMPT }
$$

Monitoring of sugarcane ${ }^{\circ}$ Brix was carried out in the field during the last four weeks prior to harvest. For the rational determination of the sugarcane harvest point, the parameter known as the Maturation Index (MI) determined in the field was used, using a portable refractometer. The MI values are: (a) less than 0.60 for green cane; (b) between 0.60 and 0.85 for cane in the process of maturation; (c) between 0.85 and 1 for mature cane; and (d) greater than 1 for cane in the process of sucrose decline (Rosseto, 2012).

The harvest was carried out on $08 / 25 / 2015$, stem yield (SY) was determined by total weighing of the stems present in the respective subplots, quantifying the weight of stems in $2 \mathrm{~m}$ of the two central lines, whose value was extrapolated to $\mathrm{th}^{-1}$. For this, the cut was made as close as possible to the soil. The stem were then untidy and had the pointer highlighted. They were then weighed in a hook-type digital scale, with a Soil Control mark (accuracy= $0.02 \mathrm{~kg}$ ), with a capacity of $50 \mathrm{~kg}$.

Samples of 10 stems per plot were collected for the determination of the percentage of raw sugar contained in stems (PRS) and free reducing sugars (FRS) in the Agrindustrial Laboratory of the Raízen Plant, in Jataí-GO, according to CONSECANA (2006) methods. To determine the quality of the technological attributes of the sugarcane, the samples were disintegrated or ground and homogenized. Then, $500 \mathrm{~g}$ of sample were removed and pressed in a hydraulic press for one minute at $250 \mathrm{kgf} \mathrm{cm}^{-2}$, resulting in two fractions: the broth and the wet cake (wet cake).

The gross sugar and alcohol yields were calculated using the amount of raw sugar determined in the technological analysis according to the methodology described by Caldas (1998):

$$
\mathrm{GSY}=\frac{\mathrm{PRS} \cdot \mathrm{SP}}{100}
$$

where,

GSY-gross sugar yield in $\mathrm{kg} \mathrm{ha}^{-1}$; PRS-Percentage of raw sugar in \% contained in stems and determined in laboratory; SP-Stems production in $\mathrm{tha}^{-1}$.

$$
\mathrm{GAY}=[(\mathrm{PRS} \cdot \mathrm{F})+\mathrm{FRS}] \cdot \mathrm{Fg} \cdot 10 \cdot \mathrm{SP}
$$

where,

GAY-gross alcohol yield in liter per ton of sugarcane; PRS-Percentage of raw sugar in \% contained in stems and determined in laboratory; F-stoichiometric transformation factor of sucrose in one molecule of glucose plus one of fructose, equal to 1,052; FRS-are the free reducing sugars in $\%$, whose values vary from 0.7 to $0.85 \%$, with the distillery using 0.7 for high PCC; Fg-Gay Lussac factor equal to 0.6475 ; SP-Stems production in $\mathrm{t} \mathrm{ha}^{-1}$.

The data obtained were analyzed statistically by variance analysis and when detected significant effects ( $\mathrm{F}$ test $5 \%$ of probability), they were adjusted to regression equations. Linear and quadratic components were tested and chosen the model with larger significant degree. The means for $\mathrm{N}$ source (urea and ammonium nitrate) were compared by the Tukey test to $5 \%$ of probability. The statistical analyses were carried out using the SAS package 8.02 (SAS, 2001).

\section{Results and Discussion}

In the growing season of $2014 / 15$, the rainfall precipitation at the experiment site was $1701.40 \mathrm{~mm}$ shown in Figure 1, close enough value for the development of sugarcane, which varies from 1500 to $2500 \mathrm{~mm}$, according to Doorenbos and Kassam (1979). However, it did not occur regularly throughout the harvest, predominating in the months of 10/2014 to $06 / 2015$. Therefore, the following two months after planting, 08/2014 to 10/2014 and at the end of the growth phase $06 / 2015$ to $08 / 2015$ the rainfall was insufficient, needing irrigation $(650.0 \mathrm{~mm}$, totaling the volume of $2351.40 \mathrm{~mm}$ during the growing cycle). 
In the analysis of variance, it was observed that there was a significant interaction between the dose and time factors for the variable dry matter of green leaves (DMGL), evidencing that the effect of the dose of nitrogen fertilization was dependent on the time of growth and development of sugarcane. On the other hand, the variables dry matter of dead leaves (DMDL) and dry pointer (DMPT) had a significant effect on the time factor, evidencing that the evaluation period had an effect during all growth stages of development of sugarcane.

In Brazil, low cane-plant responses to nitrogen fertilization are observed, possibly due to the marked dynamics of O.M. in tropical soils and by the probable occurrence of biological fixation (Urquiaga et al., 2012). As in the present study a very clayey soil with a high O.M. content was used, the nitrogen responses and the interaction of the inoculation with the nitrogen fertilization were possibly influenced by O.M. from soil.

In the unfolding of the dose factor within each season for the DMGL, it was observed that there was an estimated linear increase of 19.12 and 30.17 g plant $^{-1}$ with $180 \mathrm{~kg} \mathrm{~N} \mathrm{ha}^{-1}$, corresponding to 40.33 and $37.78 \%$, respectively, for 250 and 290 DAP. At 330 DAP, there was an estimated maximum quadratic increase of $107.34 \mathrm{~g} \mathrm{plant}^{-1}$ with $146.0 \mathrm{~kg} \mathrm{~N} \mathrm{ha}^{-1}$, corresponding to the increase of $34.10 \mathrm{~g} \mathrm{plant}^{-1}$ (31.77\%) (Figure 2A).

In the unfolding of the time factor within each $\mathrm{N}$ dose for DMDL, there was an estimated linear increase of 64.22, $82.14,95.57$ and 90.87 g plant $^{-1}$ at 330 DAP, corresponding to $89.66,89.86,89.68$ and $85.79 \%$, respectively, for 0 , 60,120 and $180 \mathrm{~kg} \mathrm{~N} \mathrm{ha}^{-1}$ (Figure 2B).

The highest accumulation of biomass from 250 to 330 DAP corroborated by study of Leite (2016), three distinct phases of growth were identified as follows: 1) 0 to 135 DAC was marked by slow growth and low accumulation of biomass accumulating $10 \%$ of total biomass; 2) 135-270 DAC, period characterized by the rapid growth that produced, on average, $65 \%$ of the total biomass; and 3) from 270 to 370 DAC, phase exhibited slower growth and represents the phase of accumulation of sugar, on average, $25 \%$ of the total biomass. A similar pattern to the accumulation of sugarcane biomass was previously described by other authors for cane-plant and ratoon cycles (Inman-Bamber et al., 2002; Gava et al., 2005; Oliveira, 2011), for various varieties, locations and environmental conditions.

For Bell \& Garside (2005) and Allison et al. (2007), these times of slow growth are related to tillering and slow production during plant establishment. After the establishment of the canopy (pointers), sugarcane is highly efficient in the conversion of light intercepted in biomass (Rae et al., 2005; Allison et al., 2007). The last phase, depicts the appearance of sugar accumulation, increasing its concentration in the stem. Low air temperatures, reduction of rainfall and reduction of photoperiod are important factors that contribute significantly to the maturation of sugarcane (Inman-Bamber et al., 2002; Allison et al., 2007).
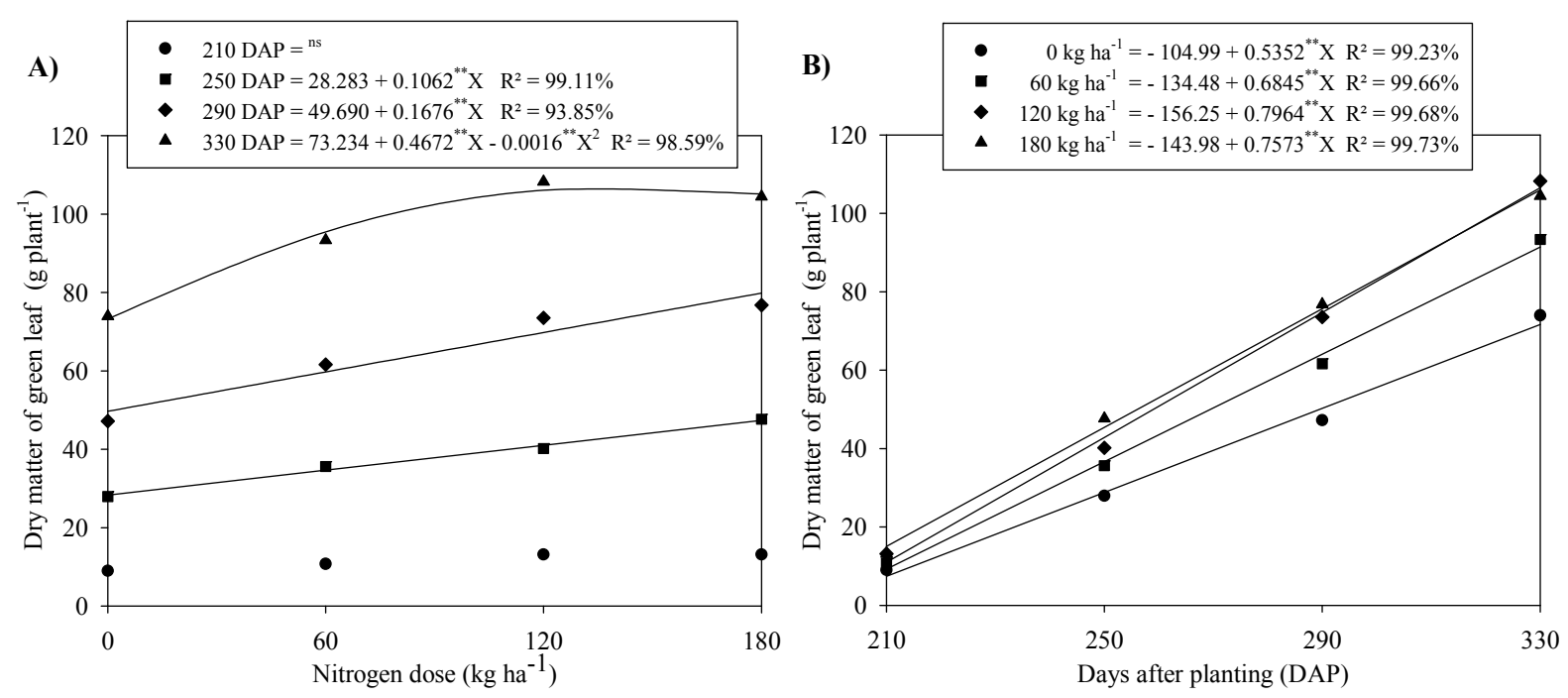

Figure 2. Dry matter of green leaf as a function of the nitrogen dose (A) and as a function of the evaluation period (B), Jataí-GO, Brazil, crop season 2014/15

Note. ${ }^{\text {ns }}$ not significant; $* *$ and $*$ significant respectively at $1 \%$ and $5 \%$ of probability, according to test $\mathrm{F}$. 
For MSFM due to DAP, it was observed that there was an estimated maximum linear increase of $74.10 \mathrm{~g} \mathrm{plant}^{-1}$ at 330 DAP, corresponding to (14.70\%) $10.89 \mathrm{~g} \mathrm{plant}^{-1}$ in relation to the 210 DAP (Figure 3A). In DMPT due to DAP, it was observed that there was an estimated maximum linear increase of $69.27 \mathrm{~g} \mathrm{plant}^{-1}$ at $330 \mathrm{DAP}$, corresponding to $(51.47 \%) 35.65 \mathrm{~g} \mathrm{plant}^{-1}$ in relation to 210 DAP (Figure $3 \mathrm{~B}$ ).
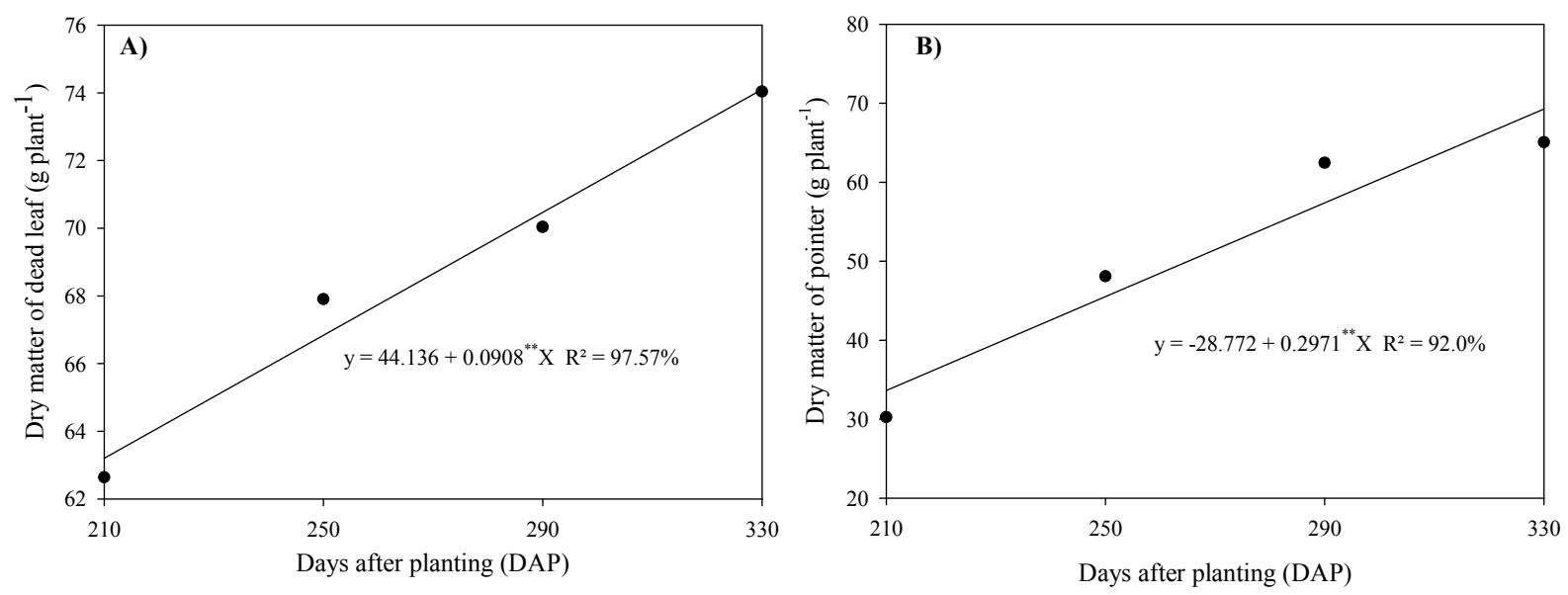

Figure 3. Dry matter of dead leaf (A) and of pointer (B), as a function of the evaluation period, Jataí-GO, Brazil, crop season $2014 / 15$

Note. $* *$ and $*$ significant respectively at $1 \%$ and $5 \%$ of probability, according to test $\mathrm{F}$.

In the analysis of variance, it was observed that there was a significant interaction between the dose and time factors for the dry matter of stem (DMS) and total dry matter of shoot (DMTAP), evidencing that the effect of the nitrogen fertilization dose was dependent on the time of growth and development of sugarcane.

Bologna-Campbell (2007) and Vitti et al. (2007) also obtained a linear response in the production of dry matter of cane-plant and the addition of $\mathrm{N}$ in the plantation (doses of 40,80 and $120 \mathrm{~kg} \mathrm{~N} \mathrm{ha}^{-1}$ ). Franco et al. (2008) observed a highly significant quadratic response $(\mathrm{p}<0.05)$ for shoot dry matter, shoot dry matter (shoot, dry leaves and pointer) and total shoot (shoots and roots), with emphasis on treatment with $80 \mathrm{~kg} \mathrm{~N} \mathrm{ha}^{-1}$.

In the unfolding within each season for DMS, there was an estimated linear increase of 90.34, 178.51, 273.546 and $258.17 \mathrm{~g}$ plant $^{-1}$ with $180 \mathrm{~kg} \mathrm{~N} \mathrm{ha}^{-1}$, corresponding to $28.43,34.21,35.39$ and $26.85 \%$, respectively, for 210,250 , 290 and 330 DAP (Figure 4A).

This result corroborates with Farias et al. (2008), because in their study they verified that the water supply through the irrigation provides an increase of the dry matter accumulation rate of the stem of the sugarcane.

In the unfolding of the time factor within each $\mathrm{N}$ dose for DMS, there was an estimated linear increase of 481.15 , $527.24,592.37$ and 658.94 g plant $^{-1}$ at 330 DAP, corresponding to $71.23,67.65,66.77$ and $68.52 \%$, respectively, for $0,60,120$ and $180 \mathrm{~kg} \mathrm{~N} \mathrm{ha}^{-1}$ (Figure 4B).

Otto et al. (2009) studied the phytomass of the sugarcane area related to the $\mathrm{N}$ fertilization of two different soils (Eutrophic Red-Yellow Latosol and Dystrophic Red Latosol), verified that the $\mathrm{N}$ fertilization of planting promoted an increase in the growth of roots and shoot part of the cane-plant in Eutrophic Red-Yellow Latosol. However, in the dystrophic Red Latosol with a large amount of organic $\mathrm{N}$ incorporated in the soil by means of crop residues. Therefore, the nitrogen fertilization of planting did not affect the growth of roots and shoot part of the cane-plant.

Kölln (2012) also observed dry matter elevation as affected by $\mathrm{N}$ dose and also irrigated management with increases as a function of the $\mathrm{N}\left(0\right.$ to $\left.140 \mathrm{~kg} \mathrm{ha}^{-1}\right)$ dose elevation of $40 \%$. For Otto et al. (2009), the efficiency of $\mathrm{N}$ utilization by plants can favor root growth, increasing nutrient uptake by sugarcane, making them better nourished, thus promoting adequate growth. 

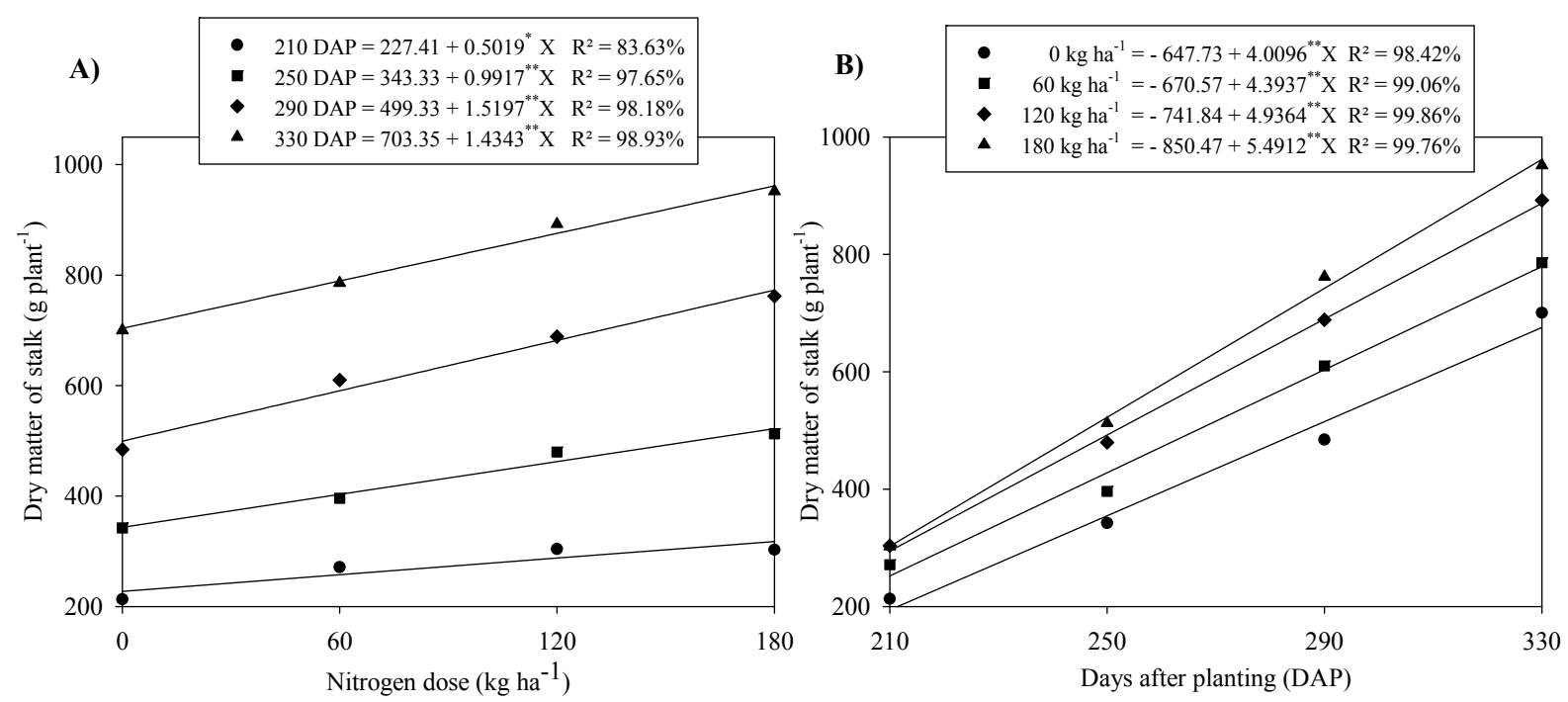

Figure 4. Dry matter of stem as affected by nitrogen dose (A) and as a function of the evaluation period (B), Jataí-GO, Brazil, crop 2014/15

Note. ${ }^{* *}$ and $*$ significant respectively at $1 \%$ and $5 \%$ of probability, according to test $\mathrm{F}$.

In the unfolding of the $\mathrm{N}$ dose factor within each season for TDMAP, there was an estimated linear increase of $104.85,220.07,328.72$ and $298.84 \mathrm{~g}$ plant $^{-1}$ with $180 \mathrm{~kg} \mathrm{~N} \mathrm{ha}^{-1}$, corresponding to $24.37,31.60,32.94$ and $24.61 \%$, respectively, for 210, 250, 290 and 330 DAP (Figure 5A).

In the unfolding of the time factor within each $\mathrm{N}$ dose for the TDMAP, it was observed that there was an estimated linear increase of $601.99,637.09,732.76$ and $800.30 \mathrm{~g}$ plant $^{-1}$ at 330 DAP, corresponding to 67.86, 63.63, 64.37, $65.54 \%$, respectively, for 0, 60, 120 and $180 \mathrm{~kg} \mathrm{~N}$ ha $^{-1}$ (Figure 5B).

The results obtained contradict Arantes (2012), who evaluated the potential productive of sugarcane cultivars under irrigated and dry land management, observed that in each evaluation period no significant effect was observed for total dry matter accumulation.

Oliveira et al. (2010), observed values between 7.5 and $12.0 \mathrm{t} \mathrm{ha}^{-1}$ for dry matter of plant (DMP) in irrigated sugarcane varieties, whose values were similar to those observed in this study.

Results observed by Carvalho (2015) show a biomass allocation in the stem started around 180 DAP. While Oliveira et al. (2010), in an irrigated trial, observed that the allocation in the stem began at 120 DAP, that the greatest accumulation of stem biomass happened from the 240 DAP, with highlight to the period from 360 days, when there was increase of about $40 \%$ in the total dry biomass of the stem until harvest. This behavior also corroborates with Oliveira et al. (2010), in irrigated condition, that registered the most significant increase between 120 and 330 DAP. Probably, this difference may have occurred due to the low precipitation during the first six months after planting in the present study. 

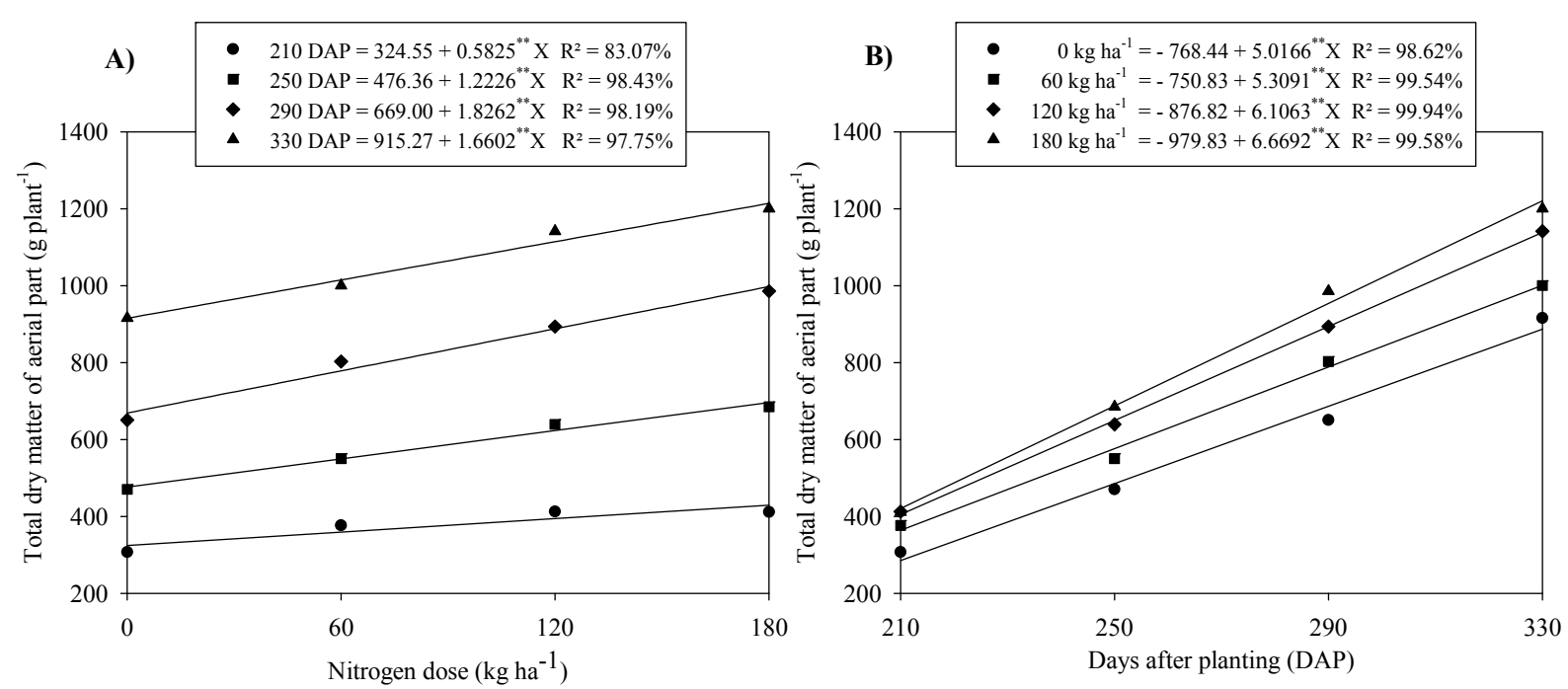

Figure 5. Total dry matter of shoot as affected by nitrogen dose (A) and as a function of the evaluation period (B), Jataí-GO, Brazil, crop season 2014/15

Note. ${ }^{* *}$ and $*$ significant respectively at $1 \%$ and $5 \%$ of probability, according to test $\mathrm{F}$.

In the analysis of variance, it was observed that the variables crude sugar yield (GSY) and crude alcohol yield (GAY) were significant for the nitrogen dose factor.

Results found by Franco et al. (2010) and Fortes et al. (2013) corroborate with this study, show an increase in sugar and alcohol yield as affected by the nitrogen fertilization in the cane-plant cycle. Silva (2014), studying the effect of irrigation and nitrogen fertilization, found a significant effect $(p<0.05)$ for both factors for GSY and GAY variables in cane-plant. The water replenishment combined with nitrogen fertilization promoted a linear increase in the crude alcohol yield.

For the GSY as a function of the dose, it is observed that there was an estimated maximum quadratic increase of $29.18 \mathrm{tha}^{-1}$ with $139.70 \mathrm{~kg} \mathrm{~N} \mathrm{ha}^{-1}$ of, corresponding to the increase of $9.76 \mathrm{t} \mathrm{ha}^{-1}(33,44 \%)$ (Figure 6A).

Regarding GAY as affected by $\mathrm{N}$ dose, it is observed that there was an estimated maximum quadratic increase of $19.80 \mathrm{~m}^{3} \mathrm{ha}^{-1}$ with $123.75 \mathrm{~kg} \mathrm{~N} \mathrm{ha}^{-1}$ of, corresponding to the increase of $6.12 \mathrm{~m}^{3} \mathrm{ha}^{-1}$ (30.94\%) (Figure 6B).

Results found by Franco (2008) show that nitrogen fertilization significantly increased sugar production per hectare. According to Gava et al. (2010), the increase of yield of irrigated sugarcane with the simultaneous application of $\mathrm{N}$-fertilizer occurs through the increase of nitrogen fertilizer utilization efficiency.

These results agree with Silva (2014), in an Oxisol, in Rio Verde, GO, Brazil, for variety RB85-5453, observed increase in GSY of (25.98\%) $9.64 \mathrm{tha}^{-1}$ and in RBAL of (26.25\%) $1.7 \mathrm{~m}^{3} \mathrm{ha}^{-1}$, in treatments irrigated with nitrogen fertilization under cane-plant conditions.

Dantas Neto et al. (2006) observed that fertilizer coverage at doses of $157 \mathrm{~kg} \mathrm{ha}^{-1}$ of $\mathrm{N}$ provided significant increases in the technological quality of sugarcane, with an increase of $39.8 \%$ for GAY. Azevedo (2002) obtained a maximum gross alcohol yield of $11.5 \mathrm{~m}^{3} \mathrm{ha}^{-1}$ with a total applied water of $1043 \mathrm{~mm}$ and a minimum crude alcohol yield of $4.8 \mathrm{~m}^{3} \mathrm{ha}^{-1}$ with the total applied water of $609 \mathrm{~mm}$. 

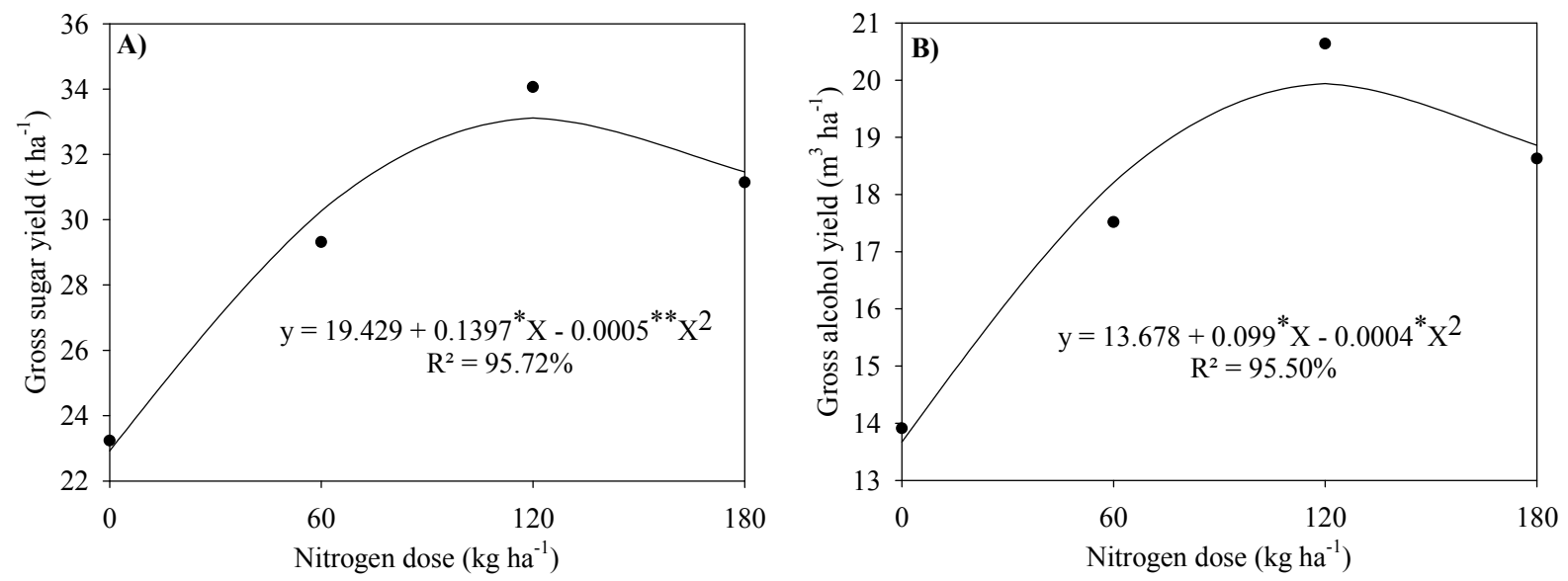

Figure 6. Gross sugar yield (A) and gross alcohol yield (B) as a function of the nitrogen dose, Jataí-GO, Brazil, crop 2014/15

Note. ${ }^{* *}$ and $*$ significant respectively at $1 \%$ and $5 \%$ of probability, according to test $\mathrm{F}$.

Cantarella (2012) assessed the sugarcane response to nitrogen application in a three-year period and found that the dry matter yield of the stem was significantly higher in urea-fertilized plants $\left(100 \mathrm{~kg} \mathrm{~N} \mathrm{ha}^{-1}\right)$, and the residual effect of this fertilization also appeared in the following year. These results demonstrate that the applications of $\mathrm{N}$ in sugarcane increase the production of dry matter of the stem and the final productivity.

Otto et al. (2009), evaluating the root and shoot biomass of the sugarcane related to the nitrogen fertilization of plantation, verified that the treatments that did not receive the nitrogen fertilizer, resulted in a higher energetic expenditure for the roots growth. Such fact that promoted competition for photoassimilates for shoot growth and may also explain the lower values for MST in treatments without application of $\mathrm{N}$-fertilizer in the present study.

\section{Conclusions}

The dry matter of dead leaveas and dry matter of pointer had increases with the evaluation period, respectively, of 14.70 and $51.47 \%$.

The highest green leaf dry matter accumulation was observed at 250 DAP $(40.33 \%)$. For dry matter of stem and total dry matter of shoot was observed at 290 DAP (34.16\%).

The source of nitrogen fertilization does not influence the accumulation of biomass of irrigated sugarcane.

The increase of the nitrogen fertilization dose provides an increase in the accumulation of dry matter of green leaf, dry matter of stem and total dry matter of aerial part.

The highest gross sugar yield and gross alcohol yield in the average source of $131.72 \mathrm{~kg} \mathrm{~N} \mathrm{ha}^{-1}$ had an average increase of $32.19 \%$, compared to without $\mathrm{N}$ application $0 \mathrm{~kg} \mathrm{~N}^{-1}$.

\section{Acknowledgements}

The authors thank the National Council for Scientific and Technological Development (CNPq), the Coordination for the Improvement for Higher Level Personnel (CAPES), the Research Support Foundation of the State of Goiás (FAPEG), the Ministry of Science, Technology, Innovation and Communications (MCTIC), the Raízen Plant Jataí unit, and the Federal Institute of Education, Science and Technology Goiano (IFGoiano)-Campus Rio Verde for the financial and structural support to conduct this study.

\section{References}

Allen, R. G., Jensen, M. E., Wright, J. L., \& Burman, R. D. (1989). Operational estimates of reference evapotranspiration. Agronomy Journal, 81, 650-662. https://doi.org/10.2134/agronj1989.000219620081000 $40019 \mathrm{x}$

Allison, J. C. S., Pammenter, N. W., \& Haslam, R. J. (2007). Why does sugarcane (Saccharum sp. hybrid) grow slowly. South African Journal Botany, 73, 546-551. https://doi.org/10.1016/j.sajb.2007.04.065

Arantes, M. T. (2012). Potencial produtivo de cultivares de cana-de-açúcar sob os manejos irrigado e sequeiro (Dissertation-Faculdade de Ciências Agronômicas da UNESP, Campus de Botucatu). 
Azevedo, H. M. (2012). Resposta da cana-de-açúcar a níveis de irrigação e de adubação de cobertura nos tabuleiros da Paraiba (Thesis, UFCG).

Bell, M. J., \& Garside, A. L. (2005). Shoot and stalk dynamics and the yield of sugarcane crops in tropical and subtropical Queensland, Australia. Field Crops Research, 92, 231-248. https://doi.org/10.1016/j.fcr.2005. 01.032

Bologna-Campbell, I. (2007). Balanço de nitrogênio e enxofre no sistema solo-cana-de-açúcar no ciclo de cana-planta (Thesis-Escola Superior de Agricultura Luiz de Queiroz).

Caldas, C. (1998). Manual de análises selecionadas para indústrias sucroalcooleiras (p. 424). Maceió: Sindicato da Indústria e do Álcool do Estado de Alagoas.

Cantarella, H. (2012). Avaliação de resposta a $\mathrm{N}$ em cana-de-açúcar não adubada por três anos. Relatório, Instituto Agronômico Centro de Solos e Recursos Ambientais, AGRISUS, Pesquisa Agronômica 719/10.

Carvalho, E. X. (2015). Ciclagem de nitrogênio e estimativa de biomassa de cana-de-açúcar em Pernambuco (Thesis, Universidade Federal de Pernambuco, Recife).

CONSECANA (Conselho dos Produtores de Cana-de-açúcar, Açúcar, Álcool do Estado de São Paulo). (2006). Manual de instruções (5th ed., p. 112). Piracicaba: CONSECANA.

Dantas Neto, J., Figueirêdo, J. L. C., Farias, C. H. A. De, Azevedo, H. M. De, \& Azevedo, C. A. V. (2006). Resposta da cana-de-açúcar, primeira soca, a níveis de irrigação e adubação de cobertura. Revista Brasileira de Engenharia Agrícola e Ambiental, 10(2), 283-288. https://doi.org/10.1590/S1415-43662006000200006

Donaldson, R. A., Redshaw, K. A., Van, R., \& Rhodes, R. A. (2008). Season effects on productivity of some commercial South African sugarcane cultivars, I: Biomass and radiation use efficiency. Proceedings of the South African Sugar Technology Association, 81, 517-527.

Doorenbos, J., \& Kassam, A. H. (1994). Efeito da água no rendimento das culturas Estudos de FAO (p. 306). Irrigação e Drenagem, Campina Grande: UFPB.

Epstein, E., \& Bloom, A. J. (2005). Mineral nutrition of plants: Principles and perpectives (p. 400). Sunderland, Sinauer Associates.

Fortes, C., Ocheuze Trivelin, P. C., Vitti, A. C., Otto, R., Franco, H. C. J., \& Faroni, C. E. (2013). Stalk and sucrose yield in response to nitrogen fertilization of sugarcane under reduced tillage. Pesquisa Agropecuária Brasileira, 48, 88-96. https://doi.org/10.1590/S0100-204X2013000100012

Franco, H. C. J., Trivelin, P. C. O., Faroni, C. E., Vitti, A. C., \& Otto, R. (2008). Aproveitamento pela cana-de-açúcar da adubação nitrogenada de plantio. Revista Brasileira de Ciência do Solo, 32, 2763-2770. https://doi.org/10.1590/S0100-06832008000700021

Franco, H. C. J., Trivelin, P. C. O., Faroni, C. E., Vitti, A. C., \& Otto, R. (2010). Stalk yield and technological attributes of planted cane as related to nitrogen fertilization. Scientia Agricola, 67, 579-590. https://doi.org/ 10.1590/S0103-90162010000500012

Gava, G. J. C., Kölln, O. T., Uribe, R. A. M., Trivelin, P. C. O., \& Cantarella, H. (2010). Interação entre água e nitrogênio na produtividade de cana-de-açúcar (Saccharum sp.). In C. A. Crusciol (Ed.), Tópicos em ecofisiolgia da cana-de-açúcar (1st ed., pp. 49-66). Botucatu: FEPAF.

Gava, G. J. D. C., Trivelin, P. C. O., Vitti, A. C., \& Oliveira, M. W. D. (2005). Urea and sugarcane straw nitrogen balance in a soil-sugarcane crop system. Pesquisa Agropecuária Brasileira, 40, 689-695. https://doi.org/10.1590/S0100-204X2005000700010

Inman-Bamber, N. G., Muchow, R. C., \& Robertson, M. J. (2002). Dry matter partitioning of sugarcane in Australia and South Africa. Field Crops Research, 76, 71-84. https://doi.org/10.1016/S0378-4290 (02)00044-8

Kölln, O. T. (2012). Interação entre os estresses de nitrogênio e disponibilidade hídrica no fracionamento isotópico de ${ }^{13}$ C e na produtividade em soqueira de cana-de-açúcar (Dissertation, Centro de Energia Nuclear na Agricultura, Universidade de São Paulo, Piracicaba).

Köppen, W., \& Geiger, R. (1928). Klimate der Erde. Gotha: Verlag Justus Perthes.

Leite, J. M. (2016). Eficiência agronômica da adubação nitrogenada associada à aplicação de substâncias húmicas em cana-de-açúcar (Thesis, Escola Superior de Agricultura “Luiz de Queiroz”, Piracicaba). 
Lelis Neto, J. A. (2012). Aplicação de vinhaça via gotejamento subsuperficial e seus efeitos nos perfis de distribuição iônico e atributos físicos e químicos de um Nitossolo (Thesis, Escola Superior de Agricultura "Luiz de Queiroz", Piracicaba).

Lima, M. A. D., \& Alves, J. B. R. (2008). Vulnerabilidades, impactos e adaptação à mudança do clima no setor agropecuário e solos agrícolas. Parcerias Estratégicas, 27(1), 360.

Malavolta, E. (2006). Manual de nutrição de plantas (p. 638). Editora Agronômica Ceres.

Marafon, A. C. (2012). Análise quantitativa de crescimento em cana-de-açúcar: Uma Introdução ao Procedimento Prático Embrapa Tabuleiros Costeiros. Aracaju, SE.

Moreira, F. M. S., \& Siqueira, J. O. (2006). Microbiologia e bioquímica do solo (2nd ed., p. 729). Lavras: UFLA.

Oliveira, E. C. A., Oliveira, R. I., Andrade, B. M. T., Freire, F. J., Lira Júnior, M. A., \& Machado, P. R. Crescimento e acúmulo de matéria seca em variedades de cana-de-açúcar cultivadas sob irrigação plena. Revista Brasileira de Engenharia Agrícola e Ambiental, 14(9), 951-960. https://doi.org/10.1590/ S1415-43662010000900007

Oliveira, E. C. A. (2011). Balanço nutricional da cana-de-açúcar relacionado à adubação nitrogenada (Thesis, Escola Superior de Agricultura "Luiz de Queiroz", Universidade de São Paulo, Piracicaba).

Otto, R., Franco, H. C. J., Faroni, C. E., Vitti, A. C., \& Trivelin, P. C. O. (2009). Fitomassa de raízes e da parte aérea da cana-de-açúcar relacionada à adubação nitrogenada de plantio. Pesquisa Agropecuária Brasileira, 44(4), 398-405. https://doi.org/10.1590/S0100-204X2009000400010

Rae, A. L., Grof, C. P. L., Casu, R. E., \& Bonnett, G. D. (2005). Sucrose accumulation in the sugarcane stem: Pathways and control points for transport and compartmentation. Field Crops Research, 92, 159-168. https://doi.org/10.1016/j.fcr.2005.01.027

Raij, B. (1991). Fertilidade do solo e adubação (p. 343). Piracicaba, SP: Ceres: Potafós.

Raij, B., Andrade, J. C., Cantarella, H., 7 Quaggio, J. A. (2001). Análise química para avaliação da fertilidade de solos tropicais (p. 284). Campinas: Instituto Agronômico.

Rossetto, R. (2012). Maturação da cana-de-açúcar. Retrieved from http://www.agencia.cnptia.embrapa.br/gestor /cana-de-acucar/arvore/CONTAG01_90_22122006154841.html

Santos, H. G., Jacomine, P. K. T., Anjos, L. H. C., Oliveira, V. A., Lumbreras, J. F., Coelho, M. R., ... Oliveira, J. B. (2013). Sistema brasileiro de classificação de solos (3rd ed., p. 353). Brasília: Embrapa.

SAS Institute Incorporation. (2001). The SAS-System for Windows release 8.02 (TS2M0) (Software). SAS Institute Inc. Cary, NC, USA.

Schultz, N., Reis, V. M., \& Urquiaga, S. (2015). Resposta da cana-de-açúcar à adubação nitrogenada: fontes nitrogenadas, formas de aplicação, épocas de aplicação e efeito varietal (p. 52). Seropédica: Embrapa Agrobiologia.

Silva, N. F. (2014). Cultivo da cana-de-açúcar submetida a diferentes lâminas de irrigação e fertirrigação nitrogenada via gotejamento subsuperficial (Dissertation, Instituto Federal Goiano-Campus Rio Verde, GO). https://doi.org/10.7127/rbai.v9n200274

Soil Survey Staff. (2010). Keys to soil taxonomy (11th ed., p. 338). Washington: United States Department of Agriculture, Natural Resources Conservation Service.

Sousa, D. M. G., \& Lobato, E. (Eds). (2004). Cerrado: Correção do solo e adubação (2nd ed., p. 416). Brasília: Embrapa Informação Tecnológica/Embrapa-CPA.

Urquiaga, S., Xavier, G. R., Morais, R. F., Batista, R. B., Schultz, N., Leite, J. M., ... Boddey, R. M. (2012). Evidence from field nitrogen balance and ${ }^{15} \mathrm{~N}$ natural abundance data for the contribution of biological $\mathrm{N}_{2}$ fixation to Brazilian sugarcane varieties. Plant and Soil, 356, 1-21. https://doi.org/10.1007/ s11104-011-1016-3

Van Heerden, P. D. R., Donaldson, R. A., Watt, D. A., \& Singels, A. (2010). Biomass accumulation in sugarcane: Unravelling the factors underpinning reduced growth phenomena. Journal of Experimental Botany, 61, 2877-2887.

Vitti, A. C., Cantarella, H., Trivelin, P. C. O., Rosseto, R. (2008). Nitrogênio. In L. L. Dinardo-Miranda, A. C. M. Vasconcelos, \& M. G. A. Landell (Eds.), Cana-de-açúcar (p. 882). Campinas: IAC. 
Vitti, A. C., Trivelin, P. C. O., Gava, G. J. C., Penatti, C. P., Bologna, I. R., Faroni, C. E., \& Franco, H. C. J. (2007). Produtividade da cana-de-açúcar relacionada ao nitrogênio residual da adubação e do sistema radicular. Pesquisa Agropecuária Brasileira, 42(2), 249-256. https://doi.org/10.1590/S0100-204X2007 000200014

Wiedenfeld, B., \& Enciso, J. (2008). Sugarcane responses to irrigation and nitrogen in semiarid South Texas. Agronomy Journal, 100, 665-671. https://doi.org/10.2134/agronj2007.0286

\section{Copyrights}

Copyright for this article is retained by the author(s), with first publication rights granted to the journal.

This is an open-access article distributed under the terms and conditions of the Creative Commons Attribution license (http://creativecommons.org/licenses/by/4.0/). 